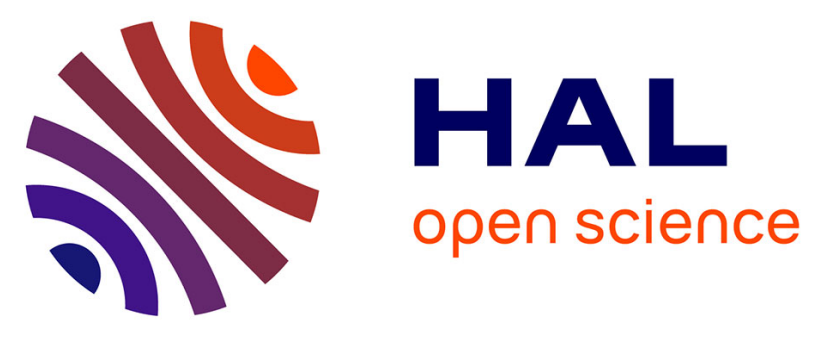

\title{
The French ST-radar network during MAP: Observational and scientific aspects
}

Jean-Luc Caccia, Jean-Pierre Aubagnac, Georges Béthenod, Christian Bourdier, Enzo Bruzzese, Bernard Campistron, Jean-Pierre Candusso, Guy Cherel, Jean-Pierre Claeyman, Jean-Louis Conrad, et al.

\section{To cite this version:}

Jean-Luc Caccia, Jean-Pierre Aubagnac, Georges Béthenod, Christian Bourdier, Enzo Bruzzese, et al.. The French ST-radar network during MAP: Observational and scientific aspects. Meteorologische Zeitschrift, 2001, 10 (6), pp.469-478. 10.1127/0941-2948/2001/0010-0469 . hal-01654054

\section{HAL Id: hal-01654054 https://hal.science/hal-01654054}

Submitted on 10 Aug 2021

HAL is a multi-disciplinary open access archive for the deposit and dissemination of scientific research documents, whether they are published or not. The documents may come from teaching and research institutions in France or abroad, or from public or private research centers.
L'archive ouverte pluridisciplinaire HAL, est destinée au dépôt et à la diffusion de documents scientifiques de niveau recherche, publiés ou non, émanant des établissements d'enseignement et de recherche français ou étrangers, des laboratoires publics ou privés.

\section{(c)(1)}

Distributed under a Creative Commons Attribution| 4.0 International License 


\title{
The French ST-radar network during MAP: Observational and scientific aspects
}

Jean-Luc Caccia ${ }^{1}$, JeAn-Pierre Aubagnac ${ }^{2}$, Georges Béthenod ${ }^{3}$, Christian Bourdier ${ }^{1}$, Enzo Bruzzese ${ }^{3}$, Bernard Campistron ${ }^{4}$, JeAn-Pierre Candusso ${ }^{1}$, Guy Cherel ${ }^{2}$, JeanPierre Claeyman ${ }^{3}$, Jean-Louis Conrad ${ }^{5}$, Roland Cordesses ${ }^{6}$, Philipp Currier ${ }^{3}$, Solène Derrien $^{4}$, Gilbert DespauX ${ }^{4}$, Juliette Dole ${ }^{5}$, Roger Durbe ${ }^{2}$, JACQUes Fournet-FAyARD $^{6}$, AlAin FrapPIER ${ }^{2}$, FABIEN GHIO ${ }^{1}$, FANNY GIRARD-ARDhUIN ${ }^{4}$, SANDRA JACOBY-KOALY ${ }^{4}$, Vladislav Klaus ${ }^{2}$, Richard $\mathrm{NeY}^{7}$, JeAn-Pierre PaGès ${ }^{4}$, Monique Petitdidier ${ }^{8}$, Yves

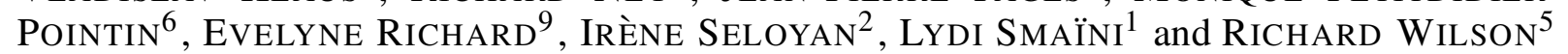

${ }^{1}$ LSEET, CNRS/Université de Toulon, La Garde; ${ }^{2}$ CNRM, Météo-France, Toulouse;

${ }^{3}$ Degréane SA, Toulon; ${ }^{4}$ CRA/LA, CNRS/Obs. Midi-Pyrénées, Campistrous;

${ }^{5}$ SA, CNRS/Université Paris VI, Jussieu, Paris; ${ }^{6}$ LAMP/OGC, CNRS/Université Blaise Pascal, Aubière;

${ }^{7}$ CETP, CNRS, St-Maur; ${ }^{8}$ CETP/UVSQ, CNRS, Vélizy; ${ }^{9}$ LA, CNRS/Obs. Midi-Pyrénées, Toulouse (all in France)

\begin{abstract}
The Mesoscale Alpine Program (MAP) international cooperative campaign took place over and around the Alps between 99/09/07 and 99/11/15 and was devoted to the study of the interactions between large-scale processes and the meso-scale flow over a complex mountainous terrain. Numerous airborne and ground based instrumental systems and meso-scale numerical models were involved in the campaign, as well as radiosoundings and satellite observations. During MAP the French ST (Strato-Tropospheric) radar researchnetwork consisted of five VHF (Very High Frequency) and three UHF (Ultra High Frequency) profilers. Four VHF's and two UHF's were installed in southern France and one VHF and one UHF were in Italy, in the Lago Maggiore target area. The VHF's provided 15-min time-resolution vertical profiles of wind and vertical SNR (Signal-to-Noise Ratio) from the low troposphere up to high tropospheric or low stratospheric levels, depending on the instrument and/or the atmospheric conditions. The same kind of data were obtained by the UHF's, but from a few hundreds of meters up to about $3 \mathrm{~km}$. In their respective altitude ranges, all these instruments allowed the time evolution and the vertical structure of meso-scale dynamic processes to be documented. VHF observations made during upper-level PV-anomaly passages (PV streamers) above southern France and Lago Maggiore area, including jet-stream passages and tropopause variations, are presented here. UHF observations of the low-tropospheric wind at the exit of the Rhône-valley, locally called Mistral, are also presented. Preliminary analyses show that our observations are consistent both between themselves and with synoptic-scale ECMWF (European Centre for Medium-Range Weather Forecasts)-model analyses. In addition, cross-comparisons with meso-scale model simulations are made allowing some meso-scale aspects of the atmospheric dynamics to be investigated.
\end{abstract}

\section{Zusammenfassung}

Eine internationale Kampagne des Mesoscale Alpine Program (MAP) fand vom 7. September bis 15. November 1999 in den Alpen statt. Sie widmete sich der Untersuchung von Wechselwirkungen zwischen großräumigen Prozessen und der mesoskaligen Strömung über komplexem, gebirgigem Untergrund. Zahlreiche Instrumentensysteme in der Luft und am Boden, mesoskalige numerische Modelle, sowie Radiosonden und Satellitenmessungen kamen bei der Kampagne zum Einsatz. Während MAP bestand das französische ST (Strato-troposphärische) Forschungsradarnetz aus fünf VHF (Very High Frequency) und drei UHF (Ultra High Frequency) Profilern. Vier VHFs und zwei UHFs waren in Südfrankreich stationiert und ein VHF sowie ein UHF befanden sich in Italien, im Gebiet des Lago Maggiore. Die VHFs lieferten in 15-minütiger Zeitauflösung Vertikalprofile des Windes und die vertikale SNR (Signal-to-Noise Ratio) von der unteren Troposphäre bis zu oberen Troposphären- und unteren Stratosphärenschichten, je nach Instrument und/oder Atmosphärenbedingungen. Die gleiche Art Daten wurde von den UHFs erzeugt, jedoch aus Höhen von einigen $100 \mathrm{~m}$ bis zu etwa $3 \mathrm{~km}$. Alle Instrumente gestatteten es, in ihrem jeweiligen Höhenbereich die zeitliche Entwicklung und die Vertikalstruktur der mesoskaligen dynamischen Prozesse aufzuzeichnen. Es werden hier VHF-Beobachtungen vorgestellt, die während des Durchgangs von Anomalien der PV (Potentielle Vorticity) - so genannte PV-streamer - über Südfrankreich und der Gegend des Lago Maggiore entstanden. Dies beinhaltet Durchgänge des Strahlstroms und Tropopausen-Variationen. Außerdem werden UHF-Beobachtungen des Winds in der unteren Troposphäre am Ausgang des Rhônetals, als Mistral bekannt, vorgestellt. Vorläufige Analysen zeigen, dass unsere Beobachtungen sowohl untereinander als auch mit Modell-Analysen im synoptischen Scale des ECMWF (European Centre for Medium-Range Weather Forecasts) konsistent sind. Darüber hinaus werden Quervergleiche mit Mesoskalen-Modellen durchgeführt, mit deren Hilfe es möglich ist, einige mesoskalige Aspekte der atmosphärischen Dynamik zu untersuchen.

\footnotetext{
*Corresponding author: Jean-Luc Caccia, LSEET, CNRS/Université de Toulon, BP 132, 83957 La Garde, France, e-mail: caccia@lseet.univ-tln.fr
} 


\section{Introduction}

The Mesoscale Alpine Program (MAP) international co-operative campaign took place over and around the Alps between 99/09/07 and 99/11/15 and was devoted to the study of the interactions between large-scale processes and meso-scale flows over a complex mountainous terrain (BINDER et al., 1995). The general objective of the campaign was to improve the weather forecasting models, mainly at meso-scales, in the Alpine area. More specifically, eight scientific objectives have been identified and can be summarized as follows: (1) orographic precipitation mechanisms, (2) incident uppertropospheric potential vorticity (PV) anomalies, (3) hydrological measurements for flood forecasting, (4) dynamics of gap flow, (5) unstationary aspects of foehn in a large valley, (6) three-dimensional gravity wave breaking, (7) potential vorticity banners, and (8) structure of the planetary boundary layer over steep orography. $\mathrm{Nu}$ merous airborne and ground based instrumental facilities and meso-scale numerical models were involved in the campaign, as well as radiosoundings and satellite observations. First results were presented by BOUGEAULT et al. (2001).

During MAP, the French ST (Strato-Tropospheric) radar research-network consisted of five VHF (Very High Frequency) and three UHF (Ultra High Frequency) profilers. Four VHF's and two UHF's were installed in southern France and one VHF and one UHF were in Italy, in the Lago Maggiore target area. A brief description of the network is given in Tab. 1 .

The VHF's provided 15-min time-resolution vertical profiles of wind and vertical-SNR (Signal-to-Noise Ratio) from the low troposphere up to high tropospheric or low stratospheric levels, depending on the instrument characteristics and/or the atmospheric reflectivity conditions. The same kind of data were obtained by the UHF's, but from a few hundred meters up to about $3 \mathrm{~km}$. All these instruments documented the time evolution and the vertical structure of meso-scale dynamic processes in their respective altitude ranges.

Our first purpose is to present wind field observations made by (i) the LNM, CLF and LPV VHF profilers (see Tab. 1 for the acronyms used and Fig. 1 or 3 for their locations), during two periods of PV-streamer passages corresponding to Intensive Observing Periods (IOP) 8/9/10/11 and IOP15, and (ii) the SCH and TLU UHF profilers, installed near the mediterranean coast, during a period of Mistral corresponding to the first part of IOP15. The general description of the different meteorological situations are made from synoptic ECMWF (European Centre for Medium-range Weather Forecasts) model analyses. In addition, comparisons with numerical simulations made by the non-hydrostatic meso-scale Meso-NH model (LAFORE et al., 1998) are presented on the case of IOP15.

Our second purpose is to present the already identified scientific projects in which the French ST-radar data will be intensively used and the scientific results which can be reasonably expected.

\section{Brief description of the used numerical models}

During the MAP campaign, the ECMWF produced routine global analyses for the four main synoptic hours, 00, 06, 12 and 18UTC using a numerical model based on a T319/L50 (triangular truncation, resolving up to wave number 319 in spectral space, linearly reduced Gaussian grid with 50 levels from the earth's surface to $1 \mathrm{hPa}$ ). The grid spacing was then close to $62 \mathrm{~km}$. The integration scheme was a semi-Lagrangian, two-timelevel semi-implicit formulation with a 20 -minute time step. The variables at each grid point included the wind, the temperature, the humidity, the cloud fraction and the water/ice content (also the pressure at surface gridpoints). Several physical processes are parameterized on the Gaussian grid including orography, stratiform and convective precipitation, ground and sea roughness, and so on.

Every 6 hours, a correction process to the predicted fields was based upon the data assimilation and analysis of the global wind, the temperature, the surface pressure and the humidity errors between the measured values and the corresponding predicted values. The fields analyzed in this paper are the filtered results of this correction process.

The meso-scale simulations have been carried out with the non-hydrostatic Meso-NH model (LAFORE et al., 1998), run over a $10 \mathrm{~km}$-resolution domain nested in a $50 \mathrm{~km}$-resolution domain. The models, integrated here from 99/11/06, 00UTC to 99/11/08, 00UTC have been initialized and forced with the French ARPEGE analysis.

\section{The radar data}

Our whole network consists of five VHF ST radars and three UHF ST radars, also called wind profilers. Tab. 1 presents the radar locations (also see Fig. 1 or 3 ) and the institutes responsible for the radar operation. Their measurements lead to the time evolution of the vertical profiles of the three wind components and of the atmospheric reflectivity observed in different directions. In brief, the wind velocity is estimated from the frequency corresponding to the mean Doppler shift obtained in the radar echo, whereas the vertical signal-to-noise ratio (SNR), discussed here, is estimated from the Doppler spectrum obtained using the vertical beam. In this paper, we only discuss the data obtained from three VHF profilers, i.e. LNM, CLF and LPV, and two UHF profilers, i.e. $\mathrm{SCH}$ and TLU. 
Table 1: Network description from West to East.

\begin{tabular}{llcc}
\hline \multicolumn{1}{c}{ Institute name } & \multicolumn{1}{c}{ Location name } & Acronym & \multicolumn{1}{c}{ Coordinates } \\
CRA/LA/OMP (VHF) & Lannemezan & LNM & $43^{\circ} 08^{\prime} \mathrm{N}, 00^{\circ} 22^{\prime} \mathrm{E}$ \\
LaMP/OPGC (VHF) & Clermont-Ferrand & CLF & $45^{\circ} 43^{\prime} \mathrm{N}, 03^{\circ} 05^{\prime} \mathrm{E}$ \\
EDF/LA (UHF) & Saint-Chamas & SCH & $43^{\circ} 32^{\prime} \mathrm{N}, 05^{\circ} 02^{\prime} \mathrm{E}$ \\
SA/CNRS (VHF) & Obs. de Haute-Provence & OHP & $43^{\circ} 54^{\prime} \mathrm{N}, 05^{\circ} 48^{\prime} \mathrm{E}$ \\
Degréane (UHF) & Toulon & TLU & $43^{\circ} 10^{\prime} \mathrm{N}, 05^{\circ} 55^{\prime} \mathrm{E}$ \\
LSEET (VHF) & Toulon & TLV & $43^{\circ} 10^{\prime} \mathrm{N}, 05^{\circ} 55^{\prime} \mathrm{E}$ \\
CNRM/Météo-France (UHF) & Lonate-Pozzolo (Italy) & LPU & $45^{\circ} 34^{\prime} \mathrm{N}, 08^{\circ} 43^{\prime} \mathrm{E}$ \\
CNRM/Météo-France (VHF) & Lonate-Pozzolo (Italy) & LPV & $45^{\circ} 34^{\prime} \mathrm{N}, 08^{\circ} 43^{\prime} \mathrm{E}$ \\
\hline
\end{tabular}
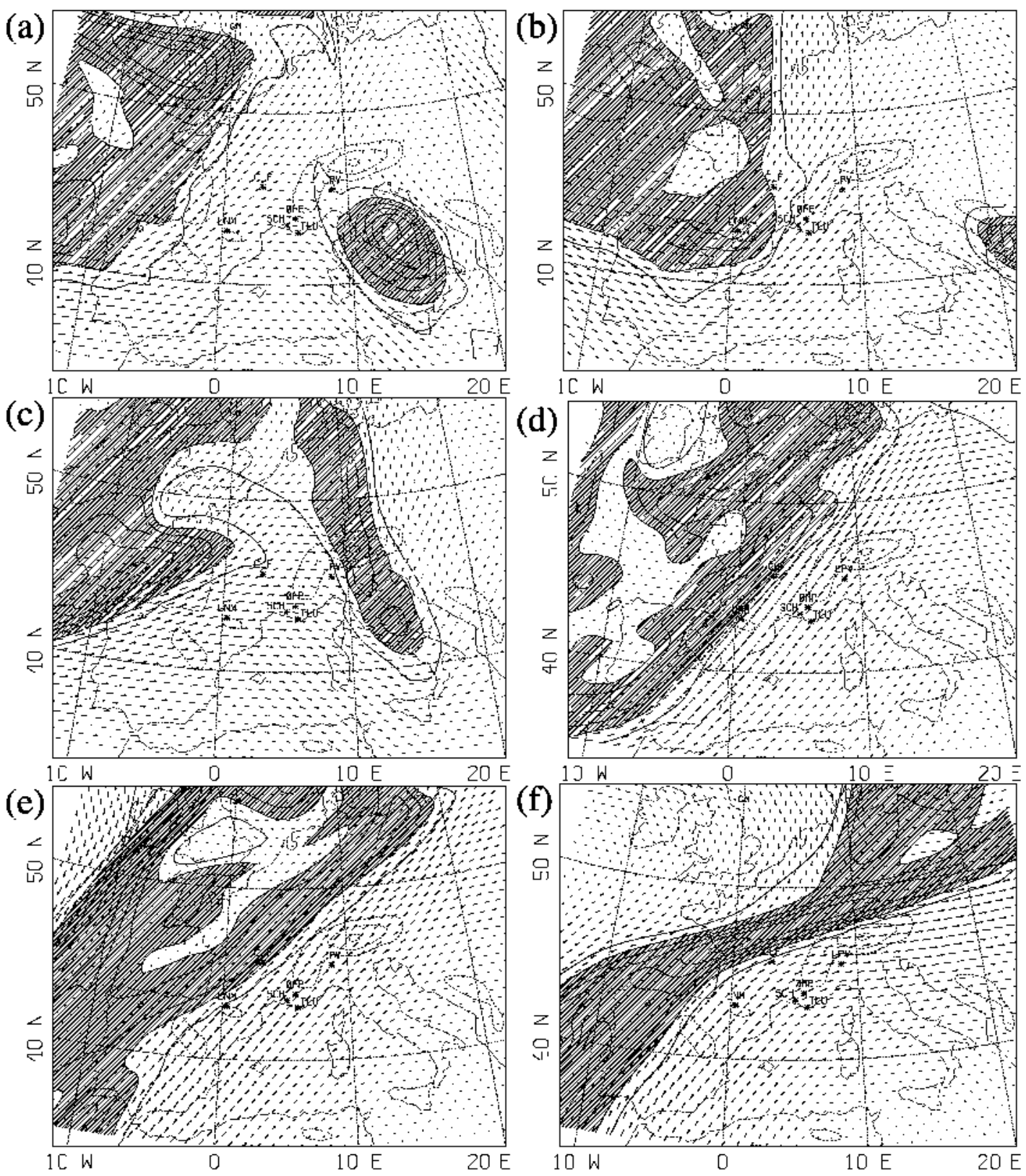

Figure 1: Wind and PV horizontal field at $300 \mathrm{hPa}(9 \mathrm{~km})$, at $00 \mathrm{UTC}$, from 99/10/22 (a) to 99/10/27 (f), from ECMWF-model analyses. The shaded areas correspond to PV $>2$ PVU. 


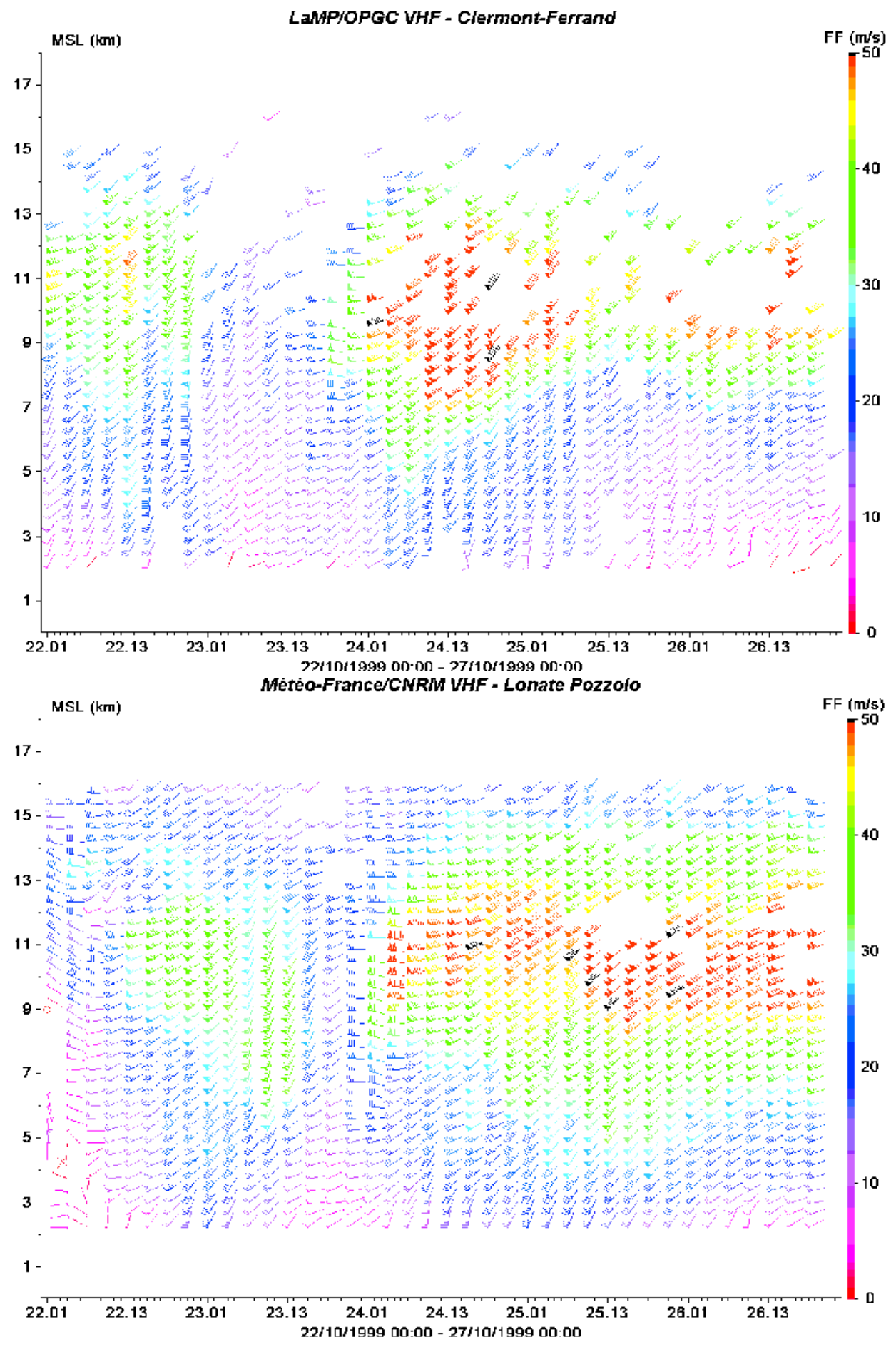

Figure 2: Time-heights diagrams of wind field (in coloured barbs) observed by the CLF (a) and LPV (b) profilers from 99/10/22 00 UTC to $99 / 10 / 2700$ UTC. A triangle stands for $50 \mathrm{~m} / \mathrm{s}$, a long barb for $10 \mathrm{~m} / \mathrm{s}$ and a short barb for $5 \mathrm{~m} / \mathrm{s}$. On the X-axis, the numbers of day of October and the UTC hours are separated by dots, e.g. 23.13 means 99/10/23, 13 UTC.

The three VHF's work with a frequency of $45 \mathrm{MHz}$, and with a peak power of $6 \mathrm{~kW}$, for LNM and CLF, and $12 \mathrm{~kW}$ for LPV. Each radar operates using five beams having a half-power beamwidth of $5^{\circ}$. Four beams are pointed by $15^{\circ}$ off-vertical in two perpendicular vertical planes and the fifth is pointed vertically. The vertical profiles of wind and reflectivity were obtained every $15 \mathrm{~min}$, but here, hourly averaged data are used and presented, since this time resolution is compatible with the time scale of a meso-scale process. A vertical resolution of $375 \mathrm{~m}$ is obtained thanks to a $25-\mu \mathrm{s}$-coded pulse with a 10-element complementary code. The investigated altitudes range between $1.5-2.0 \mathrm{~km}$ and $15.5-16 \mathrm{~km}$ ASL.

The two UHF's work with a frequency of $1238 \mathrm{MHz}$, and with a peak power of $4 \mathrm{~kW}$. They are also operated in a five-beam mode, including a vertical beam and four oblique beams with an off-zenith direction of $17^{\circ}$ and a half-power beamwidth of $8.5^{\circ}$. The profilers provide 

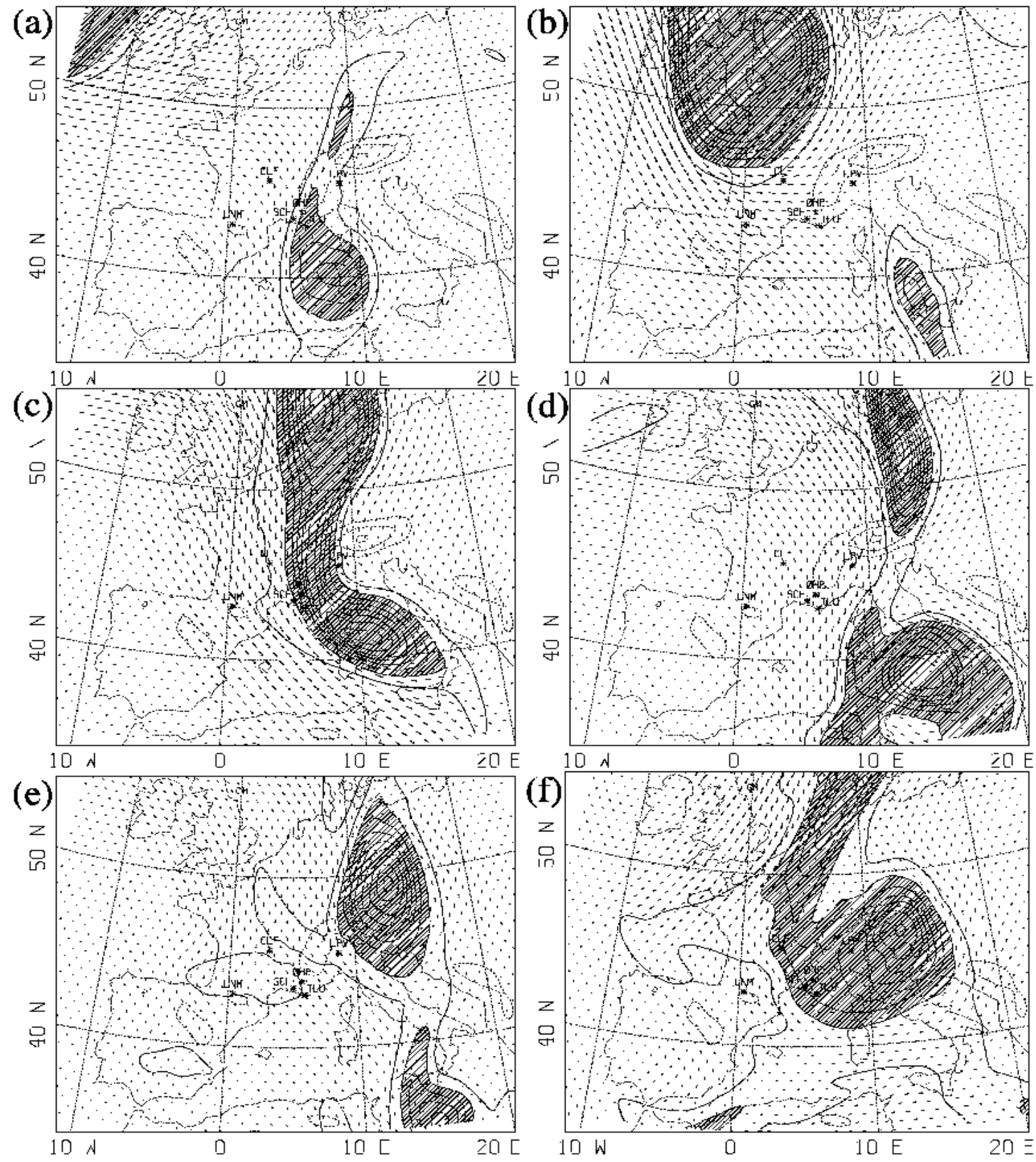

Figure 3: Same as Fig. 1 but from 99/11/05 00 UTC (a) to 99/11/10 00 UTC (f).

measurements of the three wind components, along with reflectivity, every $15 \mathrm{~min}$ from a height of 100-300 m up to $2500-4000 \mathrm{~m}$ with a $75-\mathrm{m}$ vertical-range sampling.

\section{Observations of upper-level $\mathrm{PV}$-anomaly passages}

VHF observations made during upper-level potentialvorticity (PV) anomaly passages above Southern France (IOP8/9/10/11 and IOP15) and Lago Maggiore area (IOP15), including jet stream passages and tropopause variations, are typical examples of what was expected from VHF profilers during MAP, that is, as already mentioned, an experimental height-time documentation of upper-level feature passages at meso-scale including wind field and tropopause structures.
The PV is a quasi-conserved quantity which is almost the vertical component of the absolute vorticity weighted by the vertical potential temperature gradient and by the inverse of the air density. Its commonly defined unit is $1 \mathrm{PVU}=10^{-6} \mathrm{~m}^{2} \cdot \mathrm{K} \cdot \mathrm{s}^{-1} \cdot \mathrm{kg}^{-1}$ (HosKINS et al., 1985). Due to the large value of the vertical potential temperature gradient in the stratosphere, $\mathrm{PV}$ reaches 10 PVU or more in the stratosphere, while it is usually close to zero in the troposphere. A PV $=2$ PVU-criterion is classically used to obtain the tropopause position.

\subsection{The IOP 8/9/10/11 case}

IOP $8 / 9 / 10 / 11$, i.e. from $99 / 10 / 22$ to $99 / 10 / 26$, was a typical period of incident upper-tropospheric PV-anomalies 

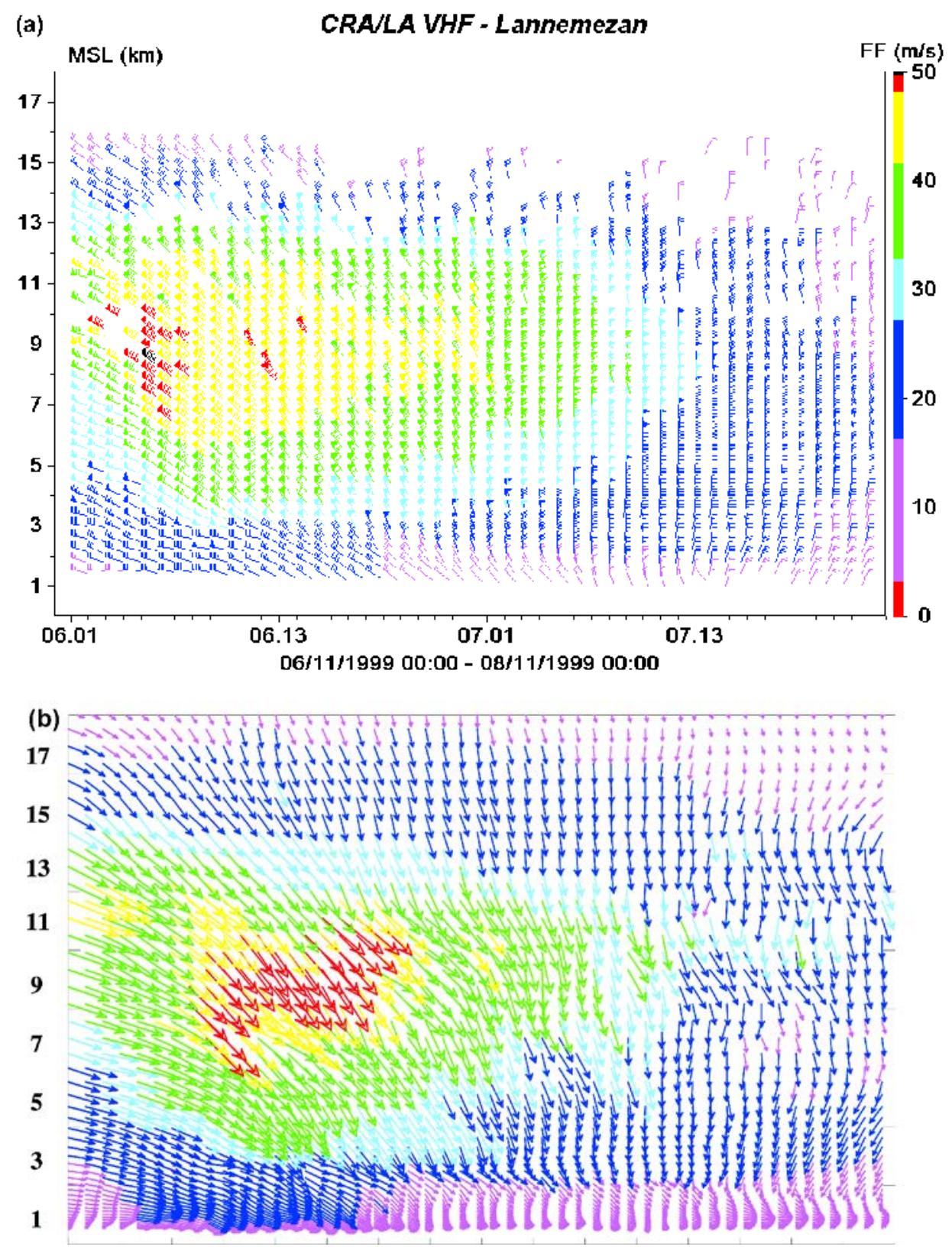

MESO-NH - Lannemezan

Figure 4: Time-height diagrams of wind field (in coloured barbs) observed by the LNM (a) profiler from 99/11/06, 00 UTC, to 99/11/08, 00 UTC (see Fig. 2 caption for time scaling and wind barb definitions), and the corresponding meso-NH simulations (b). In (b), arrows of length proportional to wind speed are used instead of wind barbs. The X-axis (48 hrs), the Y-axis (0-16 km) and the colour scale (wind speed between 0 and $50 \mathrm{~m} / \mathrm{s}$ ) are the same in (a) and (b).

arriving to the Alps from the Atlantic ocean (study related to MAP objective (2)). The horizontal wind and PV fields, at $300 \mathrm{hPa}$, from the synoptic-scale ECMWF model analyses are shown in Fig. 1 in order to describe the meteorological situation above western $\mathrm{Eu}$ rope, which can be summarized as follows. On 99/10/22 (Fig. 1a), a cut-off low is located over central Italy and moves towards the east while dissipating. A deep stationary low west of Ireland generates a weak jet stream along $40^{\circ} \mathrm{N}$ which passes over the profiler network, with a north-eastward orientation, on 99/10/22 and 99/10/23
(Figs. 1a,b). Associated to this jet stream, a weak northsouth trough and its elongated upper-level PV anomaly moves over France during 99/10/24 (Fig. 1c) while the Irish low creeps over Scotland. During the following three days (99/10/25, 99/10/26 and 99/10/27) (Figs. 1d,e,f), this low pressure system develops into a very elongated north-east south-west trough and the associated jet stream remains over the profiler network, until at least 99/10/27 (Fig. 1f).

The wind fields observed by CLF and LPV are shown, in time-height diagrams, in Fig. 2. Though not 
(c)
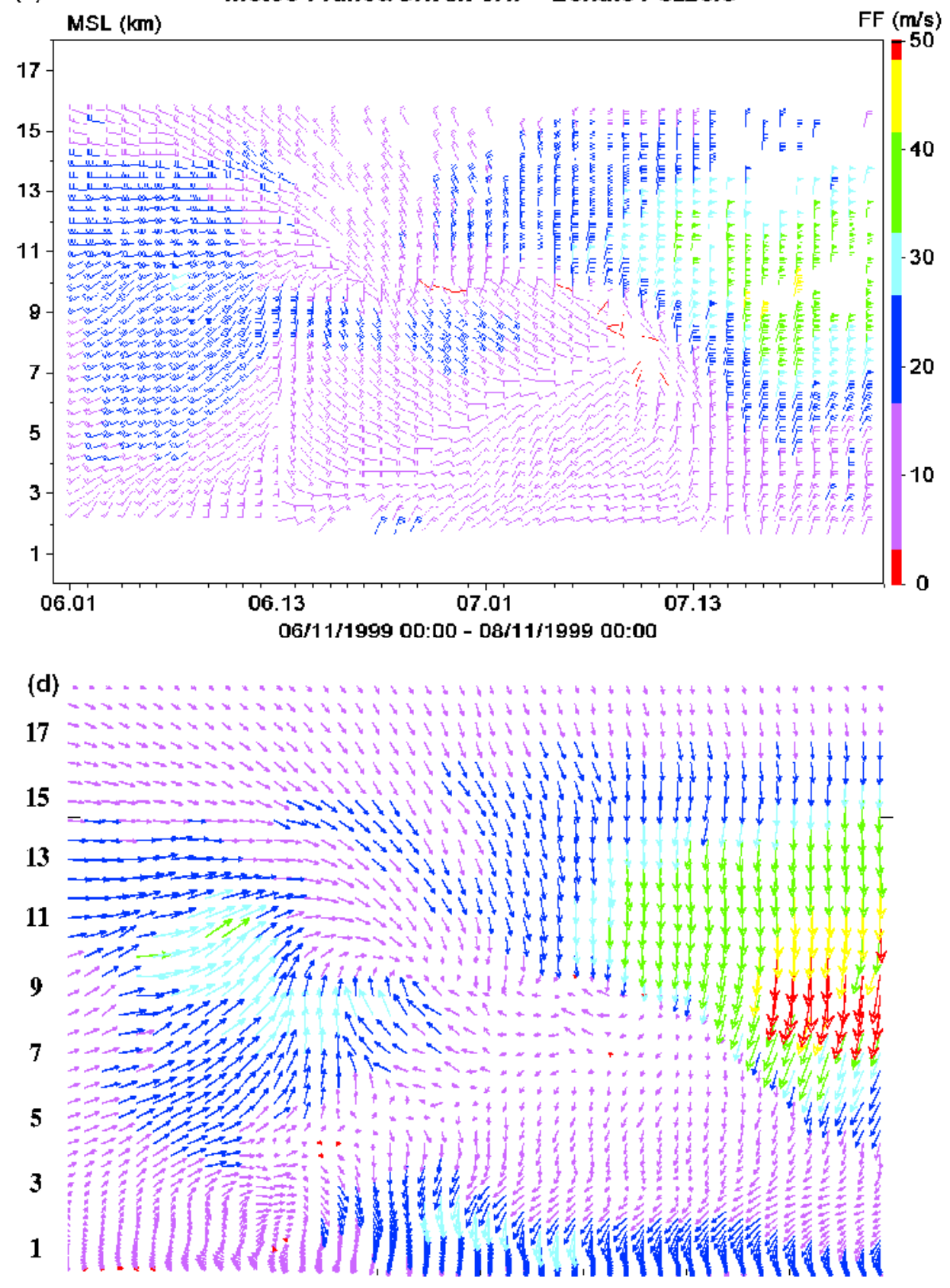

\section{MESO-NH - Lonate Pozzolo}

Figure 4 (continued): Time-height diagrams of wind field (in coloured barbs) observed by the LPV (c) profiler from 99/11/06, 00 UTC, to 99/11/08, 00 UTC (see Fig. 2 caption for time scaling and wind barb definitions), and the corresponding meso-NH simulations (d). In (d), arrows of length proportional to wind speed are used instead of wind barbs. The X-axis (48 hrs), the Y-axis (0-16 km) and the colour scale (wind speed between 0 and $50 \mathrm{~m} / \mathrm{s}$ ) are the same in (c) and (d).

shown here, the LNM profiler observed the passages of very similar structures (altitude range and wind vector) as LNM, but a few hours before, which is in agreement both with the radar locations and the propagation of the jet-stream system. During the studied period, the main features are the detection of the two jet-stream passages above the CLF and LPV radars. The first passage, which corresponds to the weak jet streak of 99/10/22 and 99/10/23 (see Figs. 1a and b), is observed above CLF around $11 \mathrm{~km}$ ASL on 99/10/22 at 12UTC (see the left part of Fig. 2a) with a maximum wind speed of $50 \mathrm{~m} / \mathrm{s}$, and about 12 hours after above LPV around $10 \mathrm{~km}$ ASL (see the left part of Fig. 2b) with a maximum wind speed of $40 \mathrm{~m} / \mathrm{s}, 99 / 10 / 23$ at 00UTC. The second, and stronger, jet stream system, which stays above the network during the last three days of the studied period (see Figs. 1d,e,f), is clearly visible on the right part of Figs. 2a and b. In both cases, a maximum wind speed about $60 \mathrm{~m} / \mathrm{s}$ is ob- 


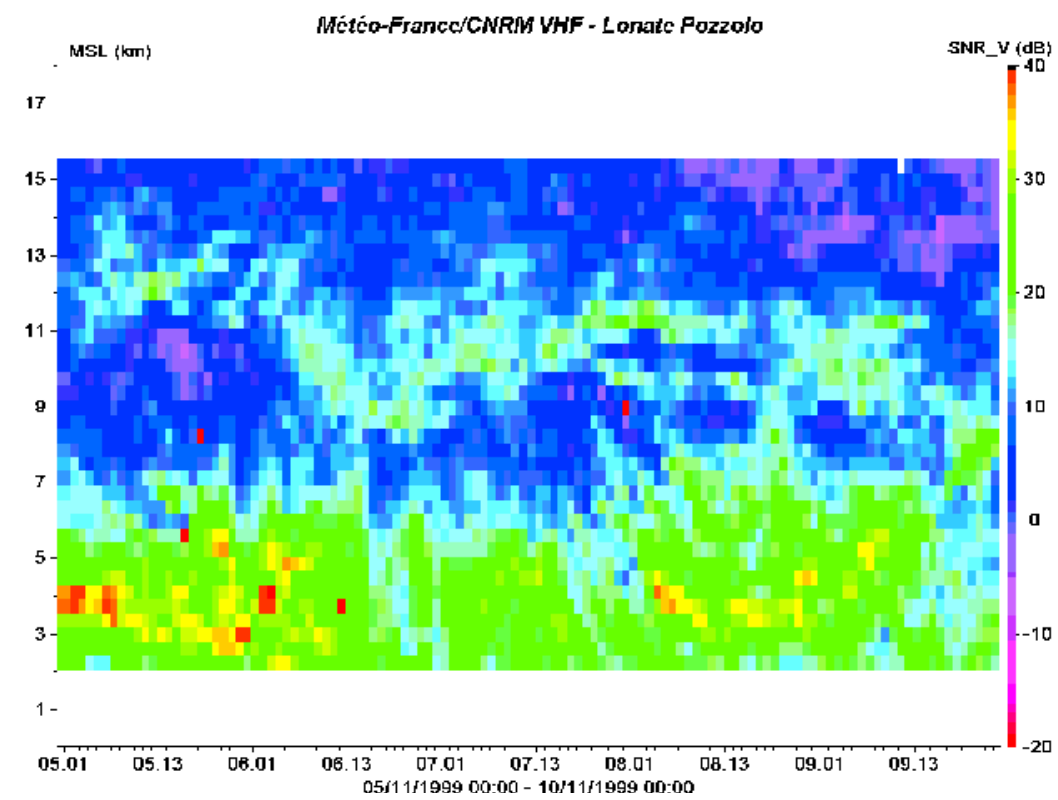

Figure 5: Time-height diagram of the vertical SNR observed by the LPV profiler during the whole IOP15, that is, from 99/11/05, 00 UTC, to 99/11/10, 00 UTC. The colour scale on the right is in dB. The upper-level SNR enhancements indicate the temporal evolution of the vertical tropopause position.

served around $10 \mathrm{~km}$ ASL. Though not compared in detail here, all these observations are consistent with the corresponding time-height wind-field structures given by the ECMWF analyses.

\subsection{The IOP15 case: comparison with Meso-NH simulations}

Passages of upper-level PV anomalies also occurred during IOP15, i.e. the $99 / 11 / 05$ to $99 / 11 / 09$-days. In addition, in this particular case the processes led to intense precipitations in and around the Alps (study related to MAP objective (1)). As for the previous case and for similar reasons, the horizontal wind and PV fields at $300 \mathrm{hPa}$ from the ECMWF model analyses are shown in Fig. 3. On 99/11/05 (Fig. 3a), a cut-off low is located over Sardinia and moves towards the east while dissipating. A very large trough centered around $50^{\circ} \mathrm{N}-0^{\circ} \mathrm{E}$ on 99/11/06 (Fig. 3b) becomes elongated towards the south and its upper-level PV anomaly covers the eastern part of the ST radar network on 99/11/07 (Fig. 3c). On 99/11/08 (Fig. 3d), a deep low develops over the Tyrrhenian Sea and leads to a cut-off low while the northern part of the trough is still active. On 99/11/09 and 99/11/10 (Figs. 3e,f), the cut-off low dissipates while the northern active trough moves southwards and becomes a quasi-cut-off low which reaches the eastern network part.

Figs. $4 \mathrm{a}$ and $4 \mathrm{c}$ show the jet-stream passage above the LNM and LPV radars, and the same kind of agreement between the LNM and CLF (not shown here) observations as for the previous case is obtained here again. This jet-stream is on the west side of, or behind, the trough, which approximately progresses towards southeast, and is oriented south-south-east above the radar locations. In the jet core, a maximum wind speed of 50$55 \mathrm{~m} / \mathrm{s}$ is measured around 7-9 $\mathrm{km}$ above LNM, in the 99/11/06 morning (left part of Fig. 4a), and slightly later, above CLF, and in the 99/11/07 afternoon above LPV (right part of Fig. 4c). In this latter case, the particularly strong wind shear, that is, about $35 \mathrm{~m} / \mathrm{s} / \mathrm{km}$, observed from the 99/11/06 afternoon until the 99/11/07 morning, between 8 and $9 \mathrm{~km}$, corresponds to the frontal surface passage and is also present both in the ECMWFmodel analyses (not shown here) and the Meso-NHmodel simulation (see Fig. 4d). Despite the existence of some discrepancies, the wind fields observed by the profilers (see Figs. 4a and c) and those simulated by Meso-NH (see Figs. 4b and d) are found to be in global agreement, which is an encouraging result. The upperlevel PV anomaly passage is also characterized by a well-marked tropopause descent, down to $8 \mathrm{~km}$, visible around 18UTC on 99/11/06 from the vertical SNR enhancements (e.g. RöTTGER, 1979) observed by the LPV VHF radar, which indicate the time evolution of the tropopause position (see the upper-level patterns on Fig. 5). Although a specific processing of the vertical and oblique SNR data (CACCIA et al., 2000), allowing the tropopause structures to be more clearly and fully monitored, remains to be made, the preliminary observations presented here are at least consistent with the ECMWF analyses.

\section{Observations of Mistral and comparison with Meso-NH simulations}

The Mistral is a violent low-tropospheric wind blowing southward along the Rhône valley. Such a wind regime 

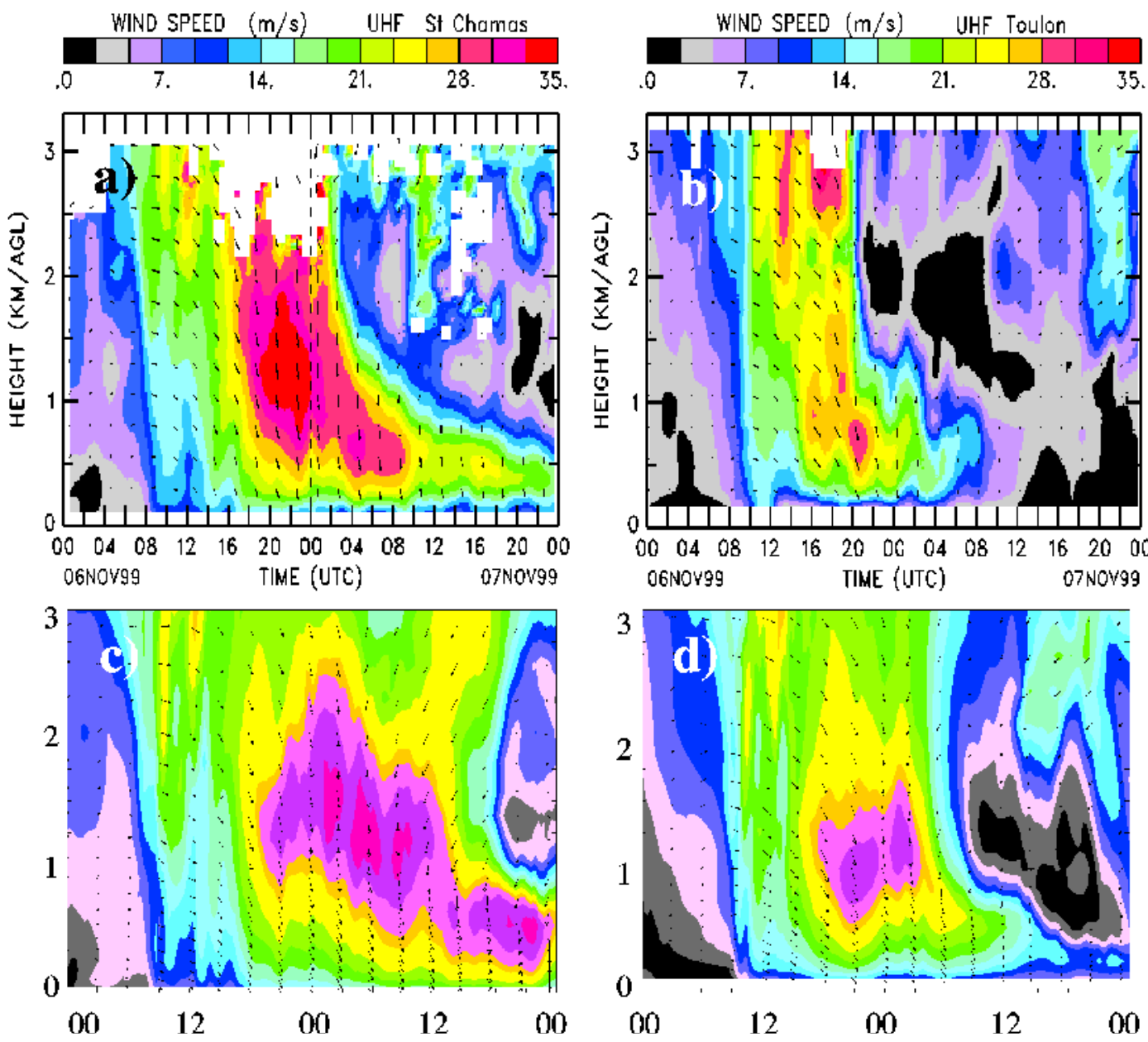

Figure 6: Same as Fig. 4 but for the SCH (a) and TLU (b) UHF profilers. The radar and meso-NH model wind fields are given in coloured levels with superimposed arrows indicating the wind direction. The same wind speed scale, i.e. $0-35 \mathrm{~m} / \mathrm{s}$, time scale and altitude range, i.e. 0-3 km-AGL, are used in (a), (b), (c) and (d).

is very well known in the South-Eastern France area, since it is a dominant meso-scale dynamical process during fall and spring. Despite its importance, there are only a few scientific studies of this specific process (e.g. PETTRÉ, 1982) or even of similar valley-wind regimes (e.g. SMiTh, 1987). A well-marked Mistral situation (study related to MAP objective (7)) occurred during the first part of IOP15, that is, from days 99/11/06 to $99 / 11 / 07$. The time evolution of the wind profiles observed by the SCH UHF profiler near the valley exit, at Saint-Chamas (north from Marseilles), is shown on Fig. 6a. Fig. 6b shows the same situation but observed at Toulon, about $80 \mathrm{~km}$ to the south-east and on the Mediterranean coast, by the TLU UHF profiler. A wind direction shift of 10 to $20^{\circ}$ exists between the two sites, that is, southward at Saint-Chamas, which is a classical Mistral feature, and south-south-eastward at Toulon. In addition, a maximum wind speed of $35-40 \mathrm{~m} / \mathrm{s}$ is observed at $1200 \mathrm{~m}$ ASL above $\mathrm{SCH}$, whereas it is around $30 \mathrm{~m} / \mathrm{s}$ at $700 \mathrm{~m}$ ASL above Toulon. Finally, it is clear that the beginning of the Mistral situation is quasi-simultaneously observed by both profilers, but its duration above SCH is twice that above TLU. Most of these results are also visible from Meso-NH simulations (Figs. 6c and 6d) which show a reasonably good agreement with the radar observations. The largest discrepancy is for $\mathrm{SCH}$ where the model overestimated the duration of the Mistral. From ECMWF analysis, it can be seen that Saint-Chamas is located on the eastern edge of the Mistral flow, or western edge of the trough, in a region of very sharp gradient (see Fig. 3c). An accurate description of the precise timing of the Mistral onset and cessation is therefore a quite severe test that will be used to assess the quality of the future and more refined simulations.

\section{Concluding remarks and future works}

Preliminary results presented here show that, at least for the periods and for the instruments studied here, UHF and VHF observations are consistent both between themselves and with synoptic-scale ECMWFmodel analyses. Since the studied processes are typically meso-scale, some cross-comparisons with MesoNH simulations are also made. Despite some discrepancies still to be explained an encouraging agreement is obtained. 
Regarding meso-scale model validation being one of the main purposes of MAP, future work will consist of deepening the analysis of the comparisons between observations and model simulations. In the case of PV-streamer passages, the cross-comparisons should also contribute to extend the validation of radar methods devoted to monitor the tropopause level and the tropospheric regions of enhanced stability, such as those occurring in tropopause folding episodes (CAMPISTRON et al., 1999; CACCIA et al., 2000). In Mistral case studies, model simulations/radar data comparisons should contribute to better understand the dynamics associated to this wind regime, especially in the area located from the Rhône-valley exit to the Mediterranean coast of SouthEastern France where the wind field direction varies from southward to south-eastward, respectively, and the maximum wind speed level descends while approaching the sea.

Two other scientific projects using radar profiler data are already identified but were not addressed here. First, the study of the temporal evolution of the boundary layer, including wind and turbulence fields is possible by the use of UHF profiler data. During MAP, different kinds of meso-scale processes, such as Mistral situations or dynamical processes induced by the local orography, have probably affected the boundary layer structure, i.e. its height and intensity time variations. The most typical situations will be investigated in the future.

Second, the LPV wind-profiler was located in a zone scanned by three ground-based Doppler weather radars. This experimental set-up was designed in order to obtain a complementary set of data and then to carry out studies concerning the dynamics at the limit of, and above, the convective systems. VHF radar provides only local observations, i.e. at the radar vertical direction, on wind and reflectivity variations as a function of altitude and time. In case of convective systems, due to the small convective time-scale such observations cannot be considered as a cross-section of the system. Then, the three-dimensional wind and reflectivity fields provided by the Doppler weather radars permit to localise the VHF observations relative to the convective activity within the system. A preliminary study has been conducted in order to improve the accuracy of the 3D fields by including LPV wind data. These fields were retrieved from dual Doppler weather observations, using the MANDOP (Multiple ANalytical DOPpler) analysis, adapted to Doppler radar observations over complex topography (TABARY and SCIALOM, 2001), and from the horizontal wind provided by the VHF wind-profiler included as an additional constraint (PETITDIDIER et al., 2000). In convective activity, it is very important to combine wind profiler data with Doppler weather radar data. Combinations of these data sets are fruitful to interpret the wind-profiler data within the large-scale threedimensional wind and reflectivity, retrieved from multiDoppler weather radar observations, and to gain information from VHF observations on the environment of the precipitating systems, not observed by the weather radars. Some study has been carried out as for IOP 2a (PETITDidier et al., 2000). Further studies will concern the interpretation of the VHF wind-profiler observations located in the upper part of and above the precipitating systems in terms of turbulence and waves.

\section{Acknowledgement}

The CNRS, the INSU/PATOM and Météo-France are gratefully acknowledged for their financial support. The authors are also thankful for the efforts made by the large number of international committees, working groups and staffs during the MAP Special Observing Period.

\section{References}

Binder, P., P. Bougeault, A. Buzzi, H.C. Davies, D. Heimann, K.P. Hoinka, J.P. KuetTner, D. MajewSKI, G. MAYR, H. Richner, C. SCHÄR, R.B. SMITH, R. Steinacker, H. Volkert, C.D. Whiteman, 1995: MAP Design Proposal. - MAP Programme Office, Swiss Meteorological Institute, Zurich, Switzerland, $65 \mathrm{pp}$.

Bougeault, P., P. Binder, A. Buzzi, R. Dirks, R. Houze, J. Kuettner, R.B. Smith, R. Steinacker, H. VOLKERT, 2001: The MAP Special Observing Period. - Bull. Am. Meteor. Soc. 82, 433-462.

Caccia, J.-L., F. Bertin, B. Campistron, Y. Pointin, J. VAN BAELEN, R. WILSON, 2000: Cut-off low monitoring by the French VHF-ST-radar network during the ESTIME campaign. - J. Atmos. Solar-Terr. Phys. 62, 639651.

Campistron, B., Y. Pointin, F. Lohou, J.-P. Pagès, 1999 : Aspect sensitivity of VHF radar echoes observed in the middle and upper troposphere during the passage of a cut-off low. - Radio Sci. 34, 667-680.

Hoskins, B.J., M.E. McIntyre, A.W. Robertson, 1985 : On the use and significance of isentropic potential vorticity maps. - Quart. J. Roy. Meteor. Soc. 111, 877-946.

LAfore, J.-P., J. Stein, N. Ascencio, P. Bougeault, V. Ducrocq, J. Duron, C. Fisher, C. Héreil, P. Mascart, J.-P. Pinty, E. Richard, J. Vila-Guerau, 1998: The Meso-NH atmospheric simulation system. Part I. Adiabiatic formulation and control simulations. - Annales Geophys. 16, 90-109.

Petitdidier, M., P. TABARy, J. Bigorgne, G. Scialom, V. KLAUS, 2000: Integration of VHF wind-profiler data within dual Doppler wind synthesis. - Phys. Chem. Earth 25, 1195-1199.

Pettré, P., 1982: On the problem of violent valley winds. J. Atmos. Sci. 39, 542-554.

RÖTTGER, J., 1979: VHF radar observations of a frontal passage. - J. Appl. Meteor. 18, 85-91.

SMITH, R.B., 1987: Aerial observations of the Yugoslavian Bora. - J. Atmos. Sci. 44, 269-297.

TABARY, P., G. SCIALOM, 2001: MANDOP analysis over complex orography in the context of the MAP Experiment. - J. Atmos. Oceanic Technol. 18, 1293-1314. 